\title{
Petrographic and Mechanical Analyses of Selected Granitic Rock Deposits in Ado-Ekiti, South-West Nigeria.
}

Olajide Tunmilayo Sanya ( $\boldsymbol{D}$ olajide.sanya@outlook.com )

University of Limerick https://orcid.org/0000-0002-5373-0838

Braimoh Olanrewaju Jimoh

Federal Polytechnic Ado-Ekiti

Boluwatife Olayide Dada

Federal Polytechnic Ado-Ekiti

Olushola Bamidele Nenuwa

Federal Polytechnic Ado-Ekiti

Israel Oluwaseun Taiwo

Federal Polytechnic Ado-Ekiti

\section{Research Article}

Keywords: Petrographic, Rock, Compressive Strength, Hardness, Mineral micro-textures.

Posted Date: June 10th, 2021

DOI: https://doi.org/10.21203/rs.3.rs-562826/v1

License: (9) This work is licensed under a Creative Commons Attribution 4.0 International License. Read Full License 


\section{Abstract}

In this study, the petrographic and mineralogy of selected granitic rocks on their physical and mechanical strength were evaluated. Granitic rock samples sourced from seven locations were analyzed to investigate their mineral micro-texture and compositions using petrographic examination and X-ray diffraction (XRD) analysis respectively. Mechanical properties including compressive strength and hardness of the examined rocks were performed following ASTM D7012-10 and EN 1534 standards. Their physical properties in term of specific gravity, porosity and water absorption were examined following ASTM C97/C97M. Results show that the predominant minerals in rock samples are quartz and kaolinite. Stress-strain curve displays plastic fragmentation after initial fracture in most granitic rock samples with rock samples from Olorunda Zone 9 and Olorunda Zone 2 exhibiting superior plastic deformation over a wide strain elongation. Their physical properties were within the acceptable range for construction applications.

\section{Introduction}

The study of petrographic, physical and mechanical properties of rocks is crucial when selecting rocks for geotechnical applications (Fahimifar and Soroush, 2007). Petrographic analysis of a rock sample involves the use of a petrographic microscope to identify the structure of its interlocking minerals. Distortion in a granitic rock's physical, structural as well as mechanical properties due to variations in environmental conditions including varying temperatures, different rates of heating and cooling, variation in mechanical load, weathering, etc, can result in substantial detrimental changes in their performances (Sajid et al., 2016a). Several related studies have been conducted on rocks from selected locations from different countries focusing on the interaction between their petrographic and mechanical properties (Tuğrul and Zarif, 1999; Güneş Yilmaz, Mete Goktan and Kibici, 2011; Arif et al., 2013; Petrounias et al., 2018; Aladejare, 2020).

The correlation between the petrographic characteristics and mechanical behaviours of different granites from the lower Himalayan regime, Pakistan, was studied by (Sajid et al., 2016b). They found that the predominant texture features influencing the mechanical properties are modal concentration and grain sizes of constitute minerals, rock mean grain size and grain size distribution within a rock. (Aladejare, 2020) reported the petrographic and chemical composition analyses as well as the physical and mechanical studies carried out on gabbro and granites rocks sample from Otanmaki, Finland. He concluded that though gabbro and granite rock samples are igneous rocks, their mineralogy differs. (Gunes Yilmaz, Goktan and Kibici, 2011) evaluated the influence of petrographic attribute and physicomechanical properties on diamond tool blade wear performance. They established that shore hardness, volume percentage and grain size of individual minerals in the granitic rock could be used as an indicator for diamond saw blade wear performance. The petrographic and physicomechanical properties of alkali granites, alkali quartz syenite and nepheline syenite from Ambela, Pakistan was investigated by (Arif et al., 2013) to ascertain their application for construction applications. They proposed that all the rocks are moderately strong and their physical properties including specific gravity 
and absorption values are within the permissible range. The correlation between petrographic characteristics of clastic rocks to their strength and bursting potential was by (Meng and Pan, 2007). Their results show that the petrographic features of a clastic rock have an intrinsic influence on its strength and failure duration. (Ündül, 2016) assessed the effect of constituent minerals and their petrography on the petrophysical properties, elastic behaviours, and strength of volcanic rocks. He concluded that the mineral mass fractions have an impact on their specific gravity and loss-on-ignition (LOI) values whereas the petrographic features influence the unconfined compressive strength (UCS) and elastic properties of the rock. It is clear from previous research efforts that the mineralogy of different granitic rock vary and the petrographic features influences the rock mechanical properties and eventually their performance. Therefore, there need to assess the petrographic properties and mechanical properties of selected granitic rock deposits that are considered construction materials in Ado-Ekiti, West Nigeria.

\subsection{The Geology And Map Of The Study Area}

The geology of the study area in Ado Ekiti belongs to the Precambrian basement complex of southwestern Nigeria within the latitude of $7^{\circ} 36^{\prime} 0^{\prime \prime} \mathrm{N}$ to $7^{\circ} 40^{\prime} 0^{\prime \prime} \mathrm{N}$ and longitude $5^{\circ} 8^{\prime} 0^{\prime \prime} \mathrm{E}$ to $5^{\circ} 8^{\prime} 0^{\prime \prime} \mathrm{E}$ (Figure 1). From the geological map of Nigeria as reported in the Geological Survey of Nigerian in 1974, Nigeria comprises of Precambrian to Early Paleozoic 'undifferentiated basement complex' (Geological Survey of Nigeria, 1974; Esu et al., 1996). The predominant rocks forming the basement complex are categories as the migmatite-gneiss complex, the schist belts and the Pan-African granites (Afolagboye, Talabi and Akinola, 2016). The rock formations in this location are reported to be granite rocks, charnockitic rocks, quartzite series, gneisses and migmatites (Oyedele, 2019). Outcrop of quartzites occurrence in Ado Ekiti can rise to $100 \mathrm{~m}$ above the surrounding ground level. Their exposure can be linked to continual weathering and erosion due to uneven terrain in the region (Afolagboye, Talabi and Akinola, 2016). The samples points cut across the Ado and Irepodun/Ifedoun Local Government Areas of Ekiti State. Ekiti is one of the 36 states in Nigeria aside from the Federal Capital Territory. It is located at an elevation ranging from $291 \mathrm{~m}$ at lye Ekiti in the northeastern part of the state and $765 \mathrm{~m}$ at Ogotun Ekiti of the southwestern Local Government Area on the state, respectively.

\subsection{Materials And Method 3.1 Sample collection}

Representative granitic rock samples of $50 \mathrm{~mm}$ and $40 \mathrm{~mm}$ from seven locations of the selected granitic rock deposits were identified. Rock samples were collected from each granite deposit with the aid of a geological hammer. Rock samples were labelled and kept in a sample bag. All of the block samples were collected fresh. The positions in terms of the coordinates and elevations where granitic rock samples were sourced were recorded using a global positioning system (G.P.S) and presented in Table 1. 
Table 1

Sample locations and co-ordinates

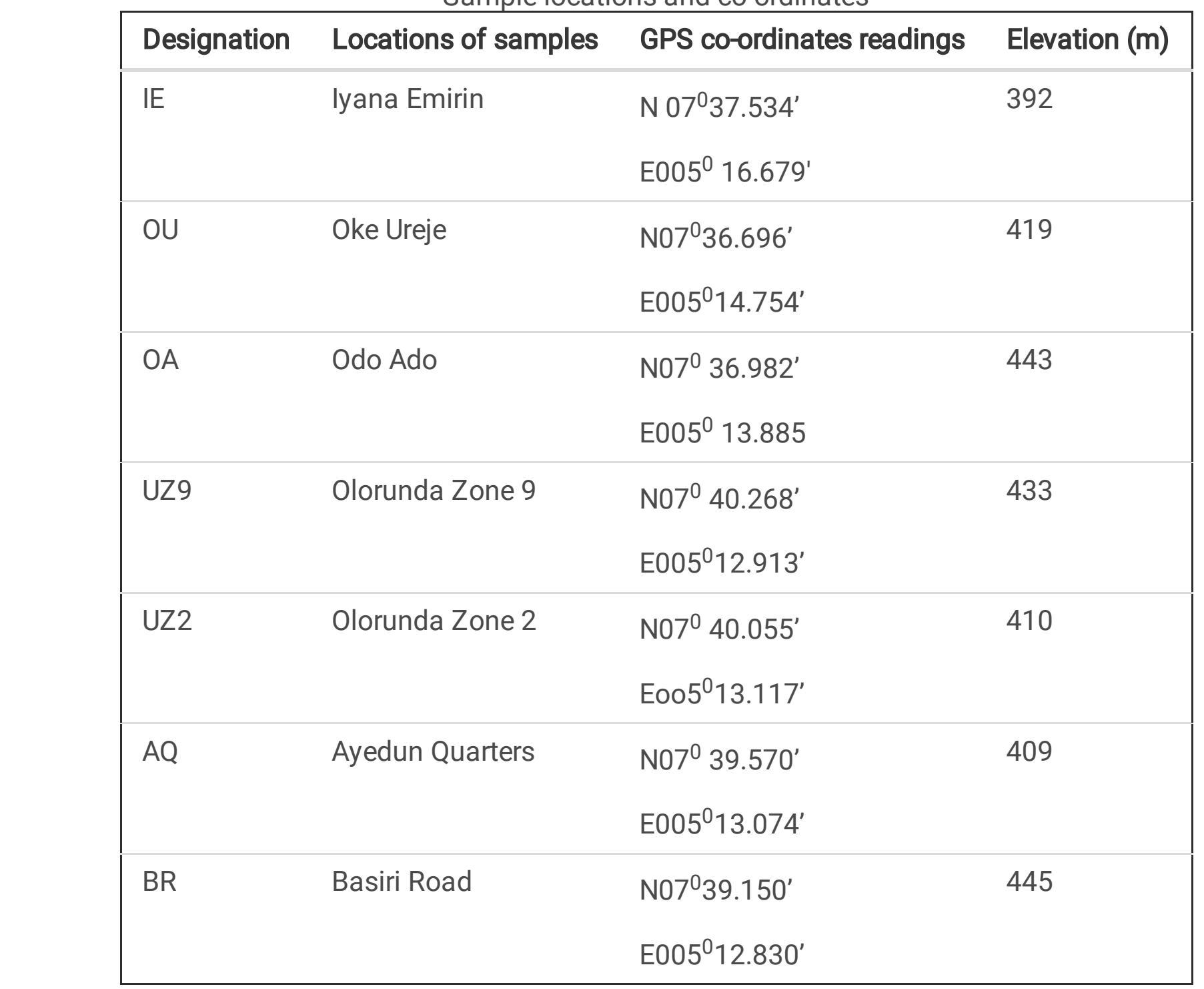

\subsection{Sample preparation}

The granitic rock samples were washed with distilled water and then dried with cleaned clothes, then were cut into required sizes with the aid of a rock cutting machine for physical and mechanical analyses, and some part of the rock samples were polished with the use of corundum powder for XRD and petrographic analyses.

\subsection{Petrographic analysis}

Petrographic examination of granitic samples was performed using Brunel petrographic microscopes equipped with a mounted DVC camera linked with a computer for the examination of prepared samples' thin section.

\subsection{Xray diffraction analysis}

X-ray Diffraction (XRD) analysis of the samples was performed by a Shimadzu XDS $2400 \mathrm{H}$ diffractometer with $\mathrm{Cu}$ anode, $\lambda 1_{\mathrm{CU}}=1.5406\left[\mathrm{~A}^{\circ}\right]$, attached to a digitized computer along with graphical 
assembly on uncompressed powders to collect the maximum of the diffraction lines and better identification of the phases.

\subsection{Compressive strength analysis}

The compressive strength analysis on the granitic rock samples was performed according to ASTM D7012-10 (ASTM, 2010). Respective samples were cut into a cube of $5 \mathrm{~cm}$ to determine the compressive strength and loaded gradually, one at a time till the first crack appears in the test specimen indicating the beginning of failure, on the base of a Universal Testing Machine (UTM).

\subsection{Hardness analysis}

Brinell hardness evaluation of the samples was measured according to British standard Brinell EN 1534 (15) using Llyod testing machine. A steel ball of $10 \mathrm{~mm}$ diameter was pressed on the surface of the samples to reach the maximum load of $3 \mathrm{KN}$ in $15 \mathrm{secs}$. The load was maintained for $25 \mathrm{secs}$ and then the load will steadily be relieved to zero within $15 \mathrm{secs}$. The indentation diameter was measured with a Brinell microscope. The mean value of hardness for seven representative samples was determined and used in the study.

\subsection{Physical properties analysis}

The physical properties of granitic rock samples that were investigated including specific gravity, porosity, and water absorption were determined according to ASTM C97/C97M (ASTM C97/C97M, 2018).

\section{Results And Discussion}

\subsection{Petrography}

The photomicrographs indicating significant features present in the selected granite rocks are presented in Fig. $2(\mathrm{a})-(\mathrm{g})$. The thin section analysis identifies the micro-texture and grain size relationships within the rock at various locations. From the photomicrographs and the chemical composition results; it is obvious that the predominant minerals in the rocks samples are quartz and kaolinite while albite, mica, muscovite, biotite, plagioclase, calcite and chloride are the secondary minerals. Quartz and kaolinite account for more than half of the mass of all the rock samples. Petrographically, the minerals present in rock samples from lyana Emirin, Odo Ado, Olorunda Zone 9 and Basiri Road locations occur in coarse and granophyric texture while their shapes range from subhedral to anhedral. Quartz occurs as a greyish and brownish coarse aggregate having on average the highest modal concentration and grain size of 2.4-5.1 $\mathrm{mm}$ in length and 1.5-3.9 $\mathrm{mm}$ in width that is largely unevenly distributed in samples from the four locations. However, the constituent minerals in rocks samples from Oke Ureje, Olorunda Zone 2 and Ayedun Quarter appear from medium to coarse with their shape ranging from subhedral to anhedral. The main minerals contents are plagioclase feldspar, microclinic feldspar orthoclase feldspar and quartz depending on their rock formation. 
Table 2

Mineral composites of the granitic rock samples.

\begin{tabular}{|llllllll|}
\hline Minerals & IE & OU & OA & UZ9 & UZ2 & AQ & BR \\
\hline Albite & 6.37 & 9.36 & 6.38 & 6.42 & 7.49 & 10.96 & 11.52 \\
\hline Quartz & 39.03 & 35.34 & 52.24 & 52.36 & 52.47 & 52.51 & 52.57 \\
\hline Mica & 2.81 & 1.29 & 1.31 & 2.84 & 6.16 & 7.19 & 1.35 \\
\hline Kaolinite & 20.40 & 20.16 & 20.4 & 20.39 & 20.33 & 20.34 & 20.36 \\
\hline Biotite & 1.08 & 4.43 & & & & & \\
\hline Muscovite & 10.4 & 2.38 & & 2.40 & 2.41 & & 2.46 \\
\hline Haematite & 0.48 & 0.44 & 0.48 & 0.48 & 0.50 & 2.52 & 0.53 \\
\hline Halloysite & 0.44 & & 0.44 & 0.48 & 0.48 & 0.50 & 0.61 \\
\hline Dolomite & 1.40 & 1.32 & 1.40 & 1.43 & 1.44 & & \\
\hline Plagioclase & 1.56 & 6.62 & & 0.50 & & & \\
\hline Calcite & 9.88 & 9.46 & 9.54 & 9.64 & 5.39 & & \\
\hline Chlorite & 5.42 & 5.21 & 5.22 & & & & 5.32 \\
\hline Clay mineral & 0.41 & 1.48 & 1.43 & 1.46 & 2.51 & 2.52 & 1.54 \\
\hline Total & 99.68 & 97.49 & 98.84 & 98.4 & 99.18 & 96.54 & 96.26 \\
\hline
\end{tabular}

\subsection{Compressive strength}

Figure 3 shows a plot of the results of the compressive stress against the compressive strain of the granitic rocks while their unconfined compressive strengths are presented in Table 3 . The plot in Fig. 3 shows that all the rock samples display a similar prolonged brittle deformation as the initial compressive load increases up to the compressive strain value of 0.043 . Beyond this initial brittle fragmentation, the response of their compressive stress to rise in compressive strain show substantial variations. The rock samples designated as Basiri Road, Oke Ureje, Ayedun Quarters, lyana Emirin and Odo Ado produce a substantial increase in compressive stress with a corresponding increase in strain. While Basiri Road, Oke Ureje, Ayedun Quarters and Odo Ado give high compressive stress-strain readings, they fail within a strain range of 0.07 and 0.09 , showing that the rocks are suitable for applications that require short-range elongation. Rock sample sourced from lyana Emirin shows good compressive stress-strain curve but a short-range while rock samples designated as Olorunda Zone 9 and Olorunda Zone 2 display the longest strain and superior stress-strain curve.

\subsection{Hardness}

The hardness values obtained for the seven rocks samples are shown in Table 2. The rock sample from Oke Ureje gives the highest hardness values of 48.95 while the sample from Olorunda Zone 9 has the 
lowest values of 21.68. The hardness value for the other locations is lyana Emirin (47.98), Odo Ado (36.39), Olorunda Zone 2 (32.09), Ayedun Quarter (45.15), Basiri Road (32.89). The mean value values are 38.02 while the standard deviation is 10.13 . Rock materials used for road aggregate should have a high hardness value and strength, it should be able to resist the polishing action of traffic. Hardness is a measure of the competency of rocks. Hard granitic rocks have better abrasion resistance, higher strength and resistance to wear which make them candidate materials as roadstone (Bell, 2007). Hardness can be used for estimating some physicochemical properties of rock, such properties include unit volume weight, average abrasive strength, uniaxial compressive strength, porosity and strength to blow and strength to bending (Güneş Yilmaz, Mete Goktan and Kibici, 2011). Besides this work, others have studied the relationship between hardness and unconfined compressive strength (Dearman, Baynes and Irfan, 1978; Shalabi, Cording and Al-Hattamleh, 2007; Boutrid et al., 2015).

Table 3

Physical properties of selected granites in Ado Ekiti

\begin{tabular}{|llllll|}
\hline Designation & $\begin{array}{l}\text { Hardness } \\
(\mathrm{BHN})\end{array}$ & $\begin{array}{l}\text { Density } \\
\left(\mathbf{g} / \mathbf{c m}^{3}\right)\end{array}$ & $\begin{array}{l}\text { Porosity } \\
(\%)\end{array}$ & $\begin{array}{l}\text { Water absorption } \\
(\%)\end{array}$ & $\begin{array}{l}\text { UCS } \\
(\mathrm{MPa})\end{array}$ \\
\hline IE & 47.98 & 2.67 & 1.11 & 2.59 & 0.130 \\
\hline OU & 48.95 & 2.63 & 1.01 & 2.98 & 0.037 \\
\hline OA & 36.39 & 2.69 & 0.98 & 3.04 & 0.047 \\
\hline UZ9 & 21.68 & 2.63 & 0.89 & 2.67 & 0.054 \\
\hline UZ2 & 32.09 & 2.69 & 0.81 & 2.82 & 1.232 \\
\hline AQ & 46.15 & 2.71 & 0.74 & 2.63 & 0.845 \\
\hline BR & 32.89 & 2.68 & 0.62 & 2.74 & 0.666 \\
\hline Mean & 38.02 & 2.67 & 0.88 & 2.78 & 0.430 \\
\hline STDEV & 10.13 & 0.03 & 0.17 & 0.17 & 0.484 \\
\hline
\end{tabular}

\subsection{Specific gravity}

Table 3 presents the physical properties which include specific gravity, porosity, and water absorption as well as the unconfined compressive strength of the granitic rock aggregates under the study. The specific gravity of a given rock aggregate depends on the density of its minerals and the total void volume present in the bulk materials (Bell, 2007; Afolagboye, Talabi and Akinola, 2016). The specific gravity of aggregates ranges between 2.63 and 2.71 with a standard variation of 0.03 . Owing to an estimated variation of 0.03 , it is clear from data that the changes in specific gravity quantity not significant for the various locations. The standard variation figure is consistent with the mineral composition that is presented in Table 2 . The specific gravity readings of the aggregates are reflections of minerals that made up a substantial proportion of the bulk materials including albites, quartz, mica, kaolinite, and calcites with an average density from $2.61-2.88 \mathrm{~g} / \mathrm{cm}^{3}$. Since rock aggregates with a specific gravity that 
exceed the lower limit of 2.55 are recommended to be suitable for heavy-duty construction applications, selected rock aggregates in this study are suitable for building and road constructions which is the main motivation for their extraction (Afolagboye, Talabi and Akinola, 2016).

\subsection{Porosity}

The porosity of a rock depends on the togetherness of the interlocking of its constituent mineral grains (Bell, 2007) From Table 3, the porosity of the selected granitic rocks ranged from $0.62-1.11 \%$. Sample lyana Emirin has the highest porosity while sample Basiri Road has the lowest porosity value. Other samples have the following porosity - Oke Ureje (1.01\%), Odo Ado (0.98\%), Olorunda Zone $9(0.89 \%)$, Olorunda Zone $2(0.81 \%)$ and Ayedun Quarters $(0.74 \%)$. The mean porosity is $0.88 \%$ and the standard deviation is 0.17 . The samples with higher porosity exhibit a lower level of water absorption and vice versa, this further confirmed that the porosity of a given rock does not necessarily indicate the amount of water that could be absorbed by it. Although, Bell concluded that rock with higher porosity would retain a greater amount of water (Bell, 2007).

\subsubsection{Correlation between porosity and unconfined compressive strength}

Previous works have shown that an increase in the apparent porosity of rock would result in to increase in the amount of water it can hold thereby increasing the susceptibility of the rock to fail mechanically due to chemical and microbial attacks (Dearman, Baynes and Irfan, 1978; Al-Harthi, Al-Amri and Shehata, 1999; Bell, 2007). The relationship between porosity and the unconfined compressive strength of the rock under study is presented in Fig. 4. From the graph, rock samples from all locations tend to follow the predictions reported in past research. Samples in Iyana Emirin, Oke Ureje, Odo Ado and Olorunda Zone 9 have very high porosity readings with a corresponding low unconfined compressive strength value. As the porosity values reduce from left to right, for Olorunda Zone 2 and Ayedun Quarter locations, there was a dramatic rise in strength than expected but still consistent with past research findings.

\subsection{Water absorption}

It is essential to estimate the water absorption characteristics of the aggregates since their strength and colour can be attributed to their cement content which depends on the porosity and therefore water absorption (Bell, 2007). Previous works reported that a little increase in the water content may result in a dramatic reduction in strength and deformability (Erguler and Ulusay, 2009; Arif et al., 2013; Afolagboye, Talabi and Akinola, 2016). Eze (E.O., 1997) emphasized that when rock aggregates with water absorption values that exceed $4 \%$ are considered for construction application and an additional geotechnical investigation is crucial to ascertain their suitability. Water absorption readings of aggregates under study range from $2.59-3.04 \%$ with a standard deviation of 0.17 (Table 3). Granite deposits situated at lyana Emrin and Odo Ado have the lowest and highest values, respectively. Water absorption values for all selected granitic rock aggregates are within the permissible range for construction applications. The value of the correlation coefficient between water absorption and unconfined compressive strength is 
-0.237. Like previous findings, there exists a weak negative correlation when the water absorption data are correlated with their compressive strength which justifies the claim that the aggregates with very low water absorption characteristics display better compressive strength.

\subsubsection{Correlation between water absorption and unconfined compressive strength}

Figure 5 comprises the water content of selected granites with their unconfined compressive strength to ascertain the influence of rock water content on their strength. It is obvious from the graph that rock samples with the highest moisture content readings which are sourced from Oke Ureje and Odo Ado show the least strength while rock samples from Olorunda Zone 2 and Ayedun Quarter, considerably lower moisture content display higher strength. This finding is consistent with previous reports by Eruguler and Fahimifar who affirmed that a small increase in the moisture content of granites could lead to a significant reduction in their strength (Vásárhelyi and Ván, 2006; Fahimifar and Soroush, 2007; Erguler and Ulusay, 2009). However, such is not the case for granite samples collected from Olorunda Zone 9 with similar moisture content to Ayedun Quarter yet having very low unconfined compressive strength. This suggests that in addition to the variation in moisture content, other rocks properties are responsible for the variation in their strength.

\section{Conclusions}

The following conclusions are deducted from this study:

- The major minerals present in rock samples are quartz and kaolinite with a trace amount of muscovite, biotite, and plagioclase.

- There were prolong initial brittle fragmentation in all granitic rock samples followed by short-range plastic deformation. However, the Olorunda Zone 9 and Olorunda 2 sample exhibits the most superior stress-strain behaviours.

- The density of the granitic rocks studied ranges between $2.63-2.71 \mathrm{~g} / \mathrm{cm}^{3}$. Water absorption of rock aggregates are within the acceptable range for construction applications and range from 2.59$3.04 \%$. The petrographic and mechanical properties of the selected granitic rocks are within the acceptable limit for application as construction materials.

- There exists an inverse relationship between porosity and moisture content when compare with unconfined compressive strength for most of the rock samples.

\section{Declarations}

\section{Acknowledgements}


This research did not receive any specific grant from funding agencies in the public, commercial, or notfor-profit sectors.

\section{Declaration of interests}

$\nabla$ The authors declare that they have no known competing financial interests or personal relationships that could have appeared to influence the work reported in this paper.

$\nabla$ The authors declare the following financial interests/personal relationships which may be considered as potential competing interests:

Olajide Tunmilayo Sanya Ibraimoh Olanrewaju Jimoh Boluwatife Olayide Dada Olushola Bamidele Nenuwa Israel Oluwaseun Taiwo

\section{References}

1. Afolagboye LO, Talabi AO, Akinola 00 (2016) 'Evaluation of selected basement complex rocks from Ado-Ekiti, SW Nigeria, as source of road construction aggregates'. Bull Eng Geol Env 75(2):853-865. DOI:10.1007/s10064-015-0766-1

2. Al-Harthi AA, Al-Amri RM, Shehata WM (1999) 'The porosity and engineering properties of vesicular basalt in Saudi Arabia'. Eng Geol 54(3-4):313-320. DOI:10.1016/S0013-7952(99)00050-2

3. Aladejare AE (2020) 'Characterization of the Petrographic and Physicomechanical Properties of Rocks from Otanmäki, Finland'. Geotech Geol Eng 39(3):2609-2621. DOI:10.1007/s10706-02001648-0

4. Arif $\mathrm{M}$ et al (2013) 'Petrography and physicomechanical properties of rocks from the Ambela granitic complex, NW Pakistan', The Scientific World Journal, 2013. DOI: 10.1155/2013/349381

5. ASTM (2010) 'Standard test method for compressive strength and elastic moduli of intact rock core specimens under varying states of stress and temperatures', D7012-10

6. ASTM C97/C97M, S (2018) 'Standard Test Methods for Absorption and Bulk Specific Gravity of Dimension Stone'. ASTM International

7. Bell FG (2007) 'Engineering geology', Engineering geology. DOI: 10.4324/9780429263125-12

8. Boutrid A et al (2015) 'Strength hardness rock testing'. J Min Sci 51(1):95-110.

DOI:10.1134/S1062739115010135

9. Dearman WR, Baynes FJ, Irfan TY (1978) 'Engineering grading of weathered granite'. Eng Geol 12(C):345-374. DOI:10.1016/0013-7952(78)90018-2

10. Erguler ZA, Ulusay R (2009) 'Water-induced variations in mechanical properties of clay-bearing rocks'. Int J Rock Mech Min Sci 46(2):355-370. DOl:10.1016/j.ijrmms.2008.07.002

11. Esu EO et al (1996) 'Geotechnical characterisation of Obudu damsite, Obudu, south-eastern Nigeria'. Eng Geol 42(4):285-299. DOI:10.1016/0013-7952(95)00090-9 
12. Fahimifar A, Soroush H (2007) 'A moisture index classification system for rocks (MiC System)'. Rock Mech Rock Eng 40(1):63-79. DOI:10.1007/s00603-005-0079-y

13. Geological Survey of Nigeria (1974) ‘Geological map of Nigeria. Scale 1:2000 000\&\#8217

14. Gunes Yilmaz N, Goktan RM, Kibici Y (2011) 'An investigation of the petrographic and physicomechanical properties of true granites influencing diamond tool wear performance, and development of a new wear index'. Wear 271(5-6):960-969. DOI:10.1016/j.wear.2011.04.007

15. Güneş Yilmaz N, Goktan M, R. and Kibici Y (2011) 'Relations between some quantitative petrographic characteristics and mechanical strength properties of granitic building stones'. Int J Rock Mech Min Sci 48(3):506-513. DOI:10.1016/j.ijrmms.2010.09.003

16. Meng Z, Pan J (2007) 'Correlation between petrographic characteristics and failure duration in clastic rocks'. Eng Geol 89(3-4):258-265. DOI:10.1016/j.enggeo.2006.10.010

17. Oyedele AA, Nigeria' SW (2019) 'Use of remote sensing and GIS techniques for groundwater exploration in the basement complex terrain of Ado-Ekiti. Applied Water Science 9(3):1-13. DOI:10.1007/s13201-019-0917-9

18. Petrounias $P$ et al (2018) 'The effect of petrographic characteristics and physico-mechanical properties of aggregates on the quality of concrete'. Minerals 8(12):1-21. DOI:10.3390/min8120577

19. Sajid M et al (2016a) 'Petrographic features as an effective indicator for the variation in strength of granites'. Eng Geol 202:44-54. DOI:10.1016/j.enggeo.2016.01.001

20. Sajid M et al (2016b) 'Petrographic features as an effective indicator for the variation in strength of granites', Engineering Geology. DOI: 10.1016/j.enggeo.2016.01.001

21. Shalabi FI, Cording EJ, Al-Hattamleh OH (2007) 'Estimation of rock engineering properties using hardness tests', Engineering Geology, 90(3-4), pp. 138-147. DOI: 10.1016/j.enggeo.2006.12.006

22. Tuğrul A, Zarif IH (1999) 'Correlation of mineralogical and textural characteristics with engineering properties of selected granitic rocks from Turkey'. Eng Geol 51(4):303-317. DOI:10.1016/S00137952(98)00071-4

23. Ündül Ö (2016) 'Assessment of mineralogical and petrographic factors affecting petro-physical properties, strength and cracking processes of volcanic rocks'. Eng Geol 210:10-22.

DOI:10.1016/j.enggeo.2016.06.001

24. Vásárhelyi B, Ván P (2006) 'Influence of water content on the strength of rock'. Eng Geol 84(1-2):7074. DOI:10.1016/j.enggeo.2005.11.011

\section{Figures}




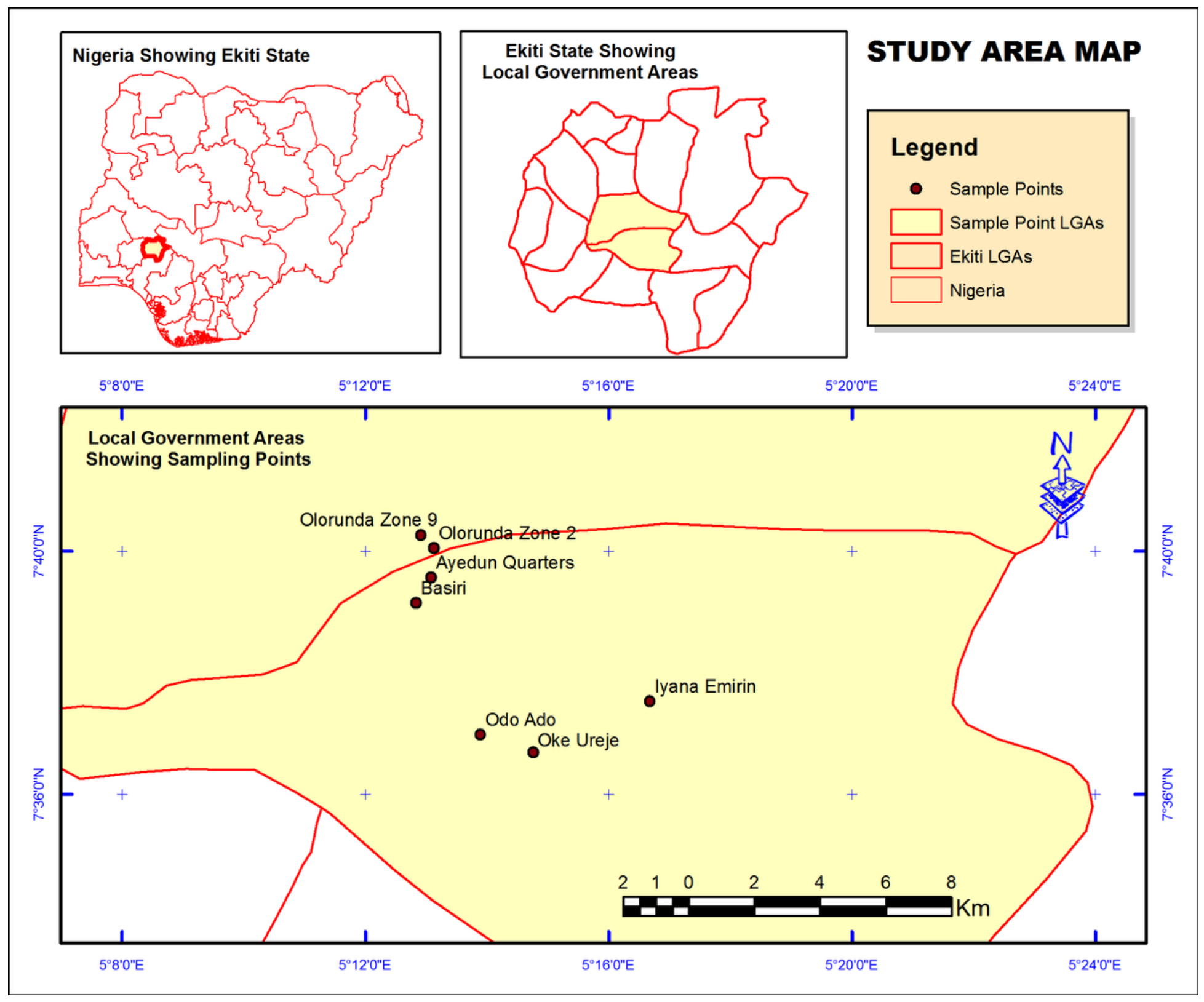

Figure 1

The study area map and coordinates. Note: The designations employed and the presentation of the material on this map do not imply the expression of any opinion whatsoever on the part of Research Square concerning the legal status of any country, territory, city or area or of its authorities, or concerning the delimitation of its frontiers or boundaries. This map has been provided by the authors. 


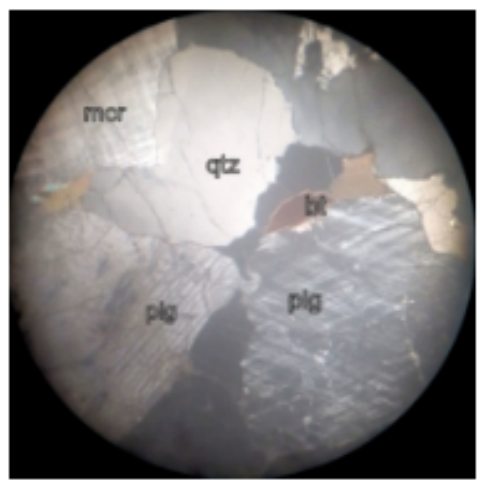

a

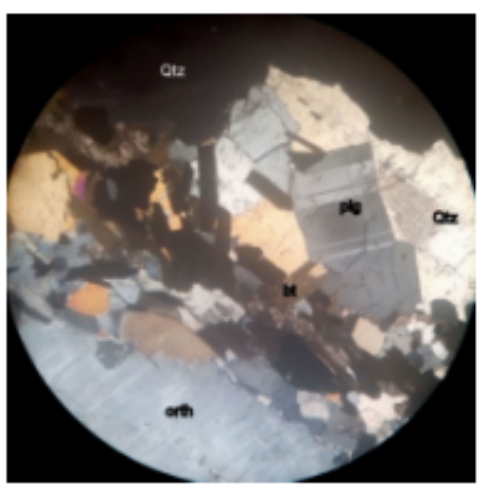

d

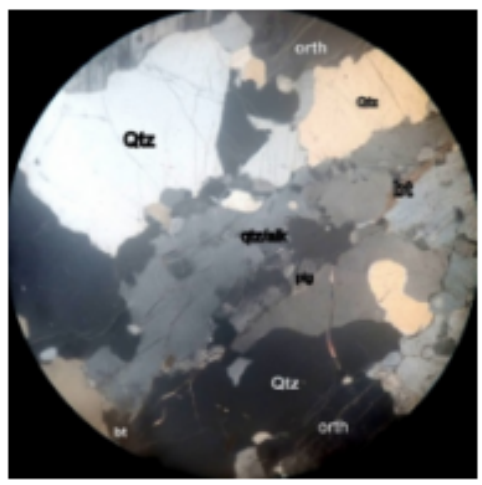

\section{g}

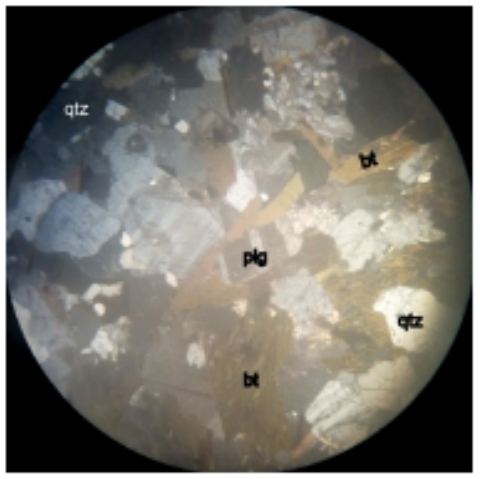

$\mathrm{b}$
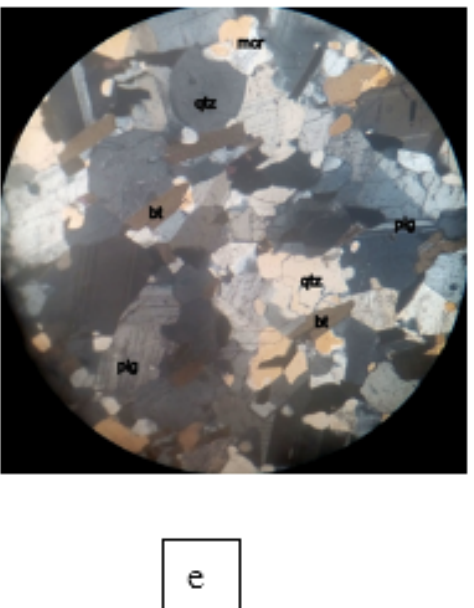
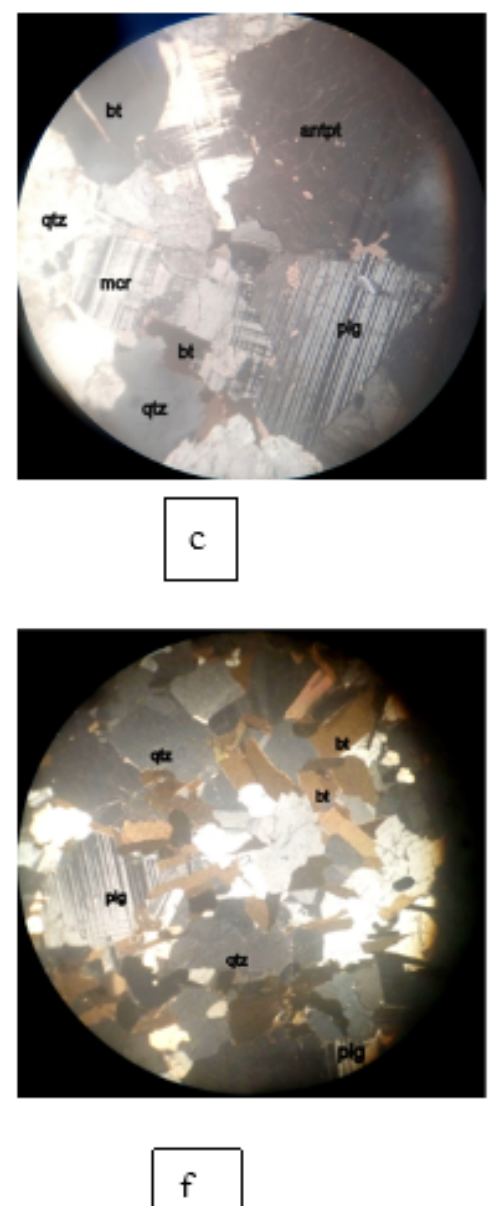

\section{Figure 2}

Photomicrographs of essential petrographic characteristics present in the granitic rock samples in the following locations (a) lyana Emirin (b) Oke Ureje (c) Odo Ado (d) Olorunda Zone 9 (e) Olorunda Zone 2 (f) Ayedun quarters and (g) Basiri Road. CN 40x(Cross Nikon 40x magnification). Qtz: quartz, Pig: Plagioclase, Bt: Biotite, Mcr: muscovite. Note: The designations employed and the presentation of the material on this map do not imply the expression of any opinion whatsoever on the part of Research 
Square concerning the legal status of any country, territory, city or area or of its authorities, or concerning the delimitation of its frontiers or boundaries. This map has been provided by the authors.

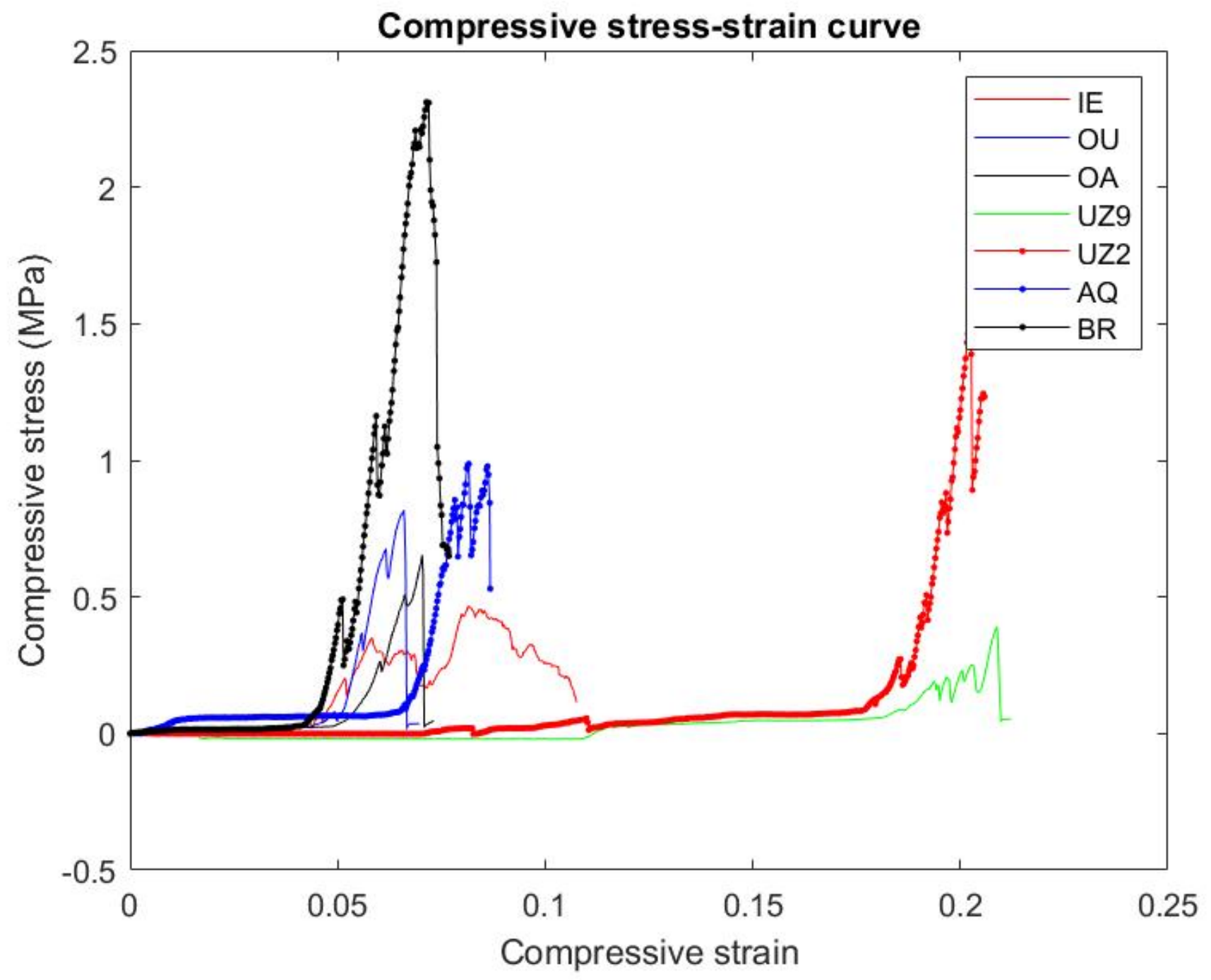

Figure 3

Compressive stress-strain curve of granitic rock 


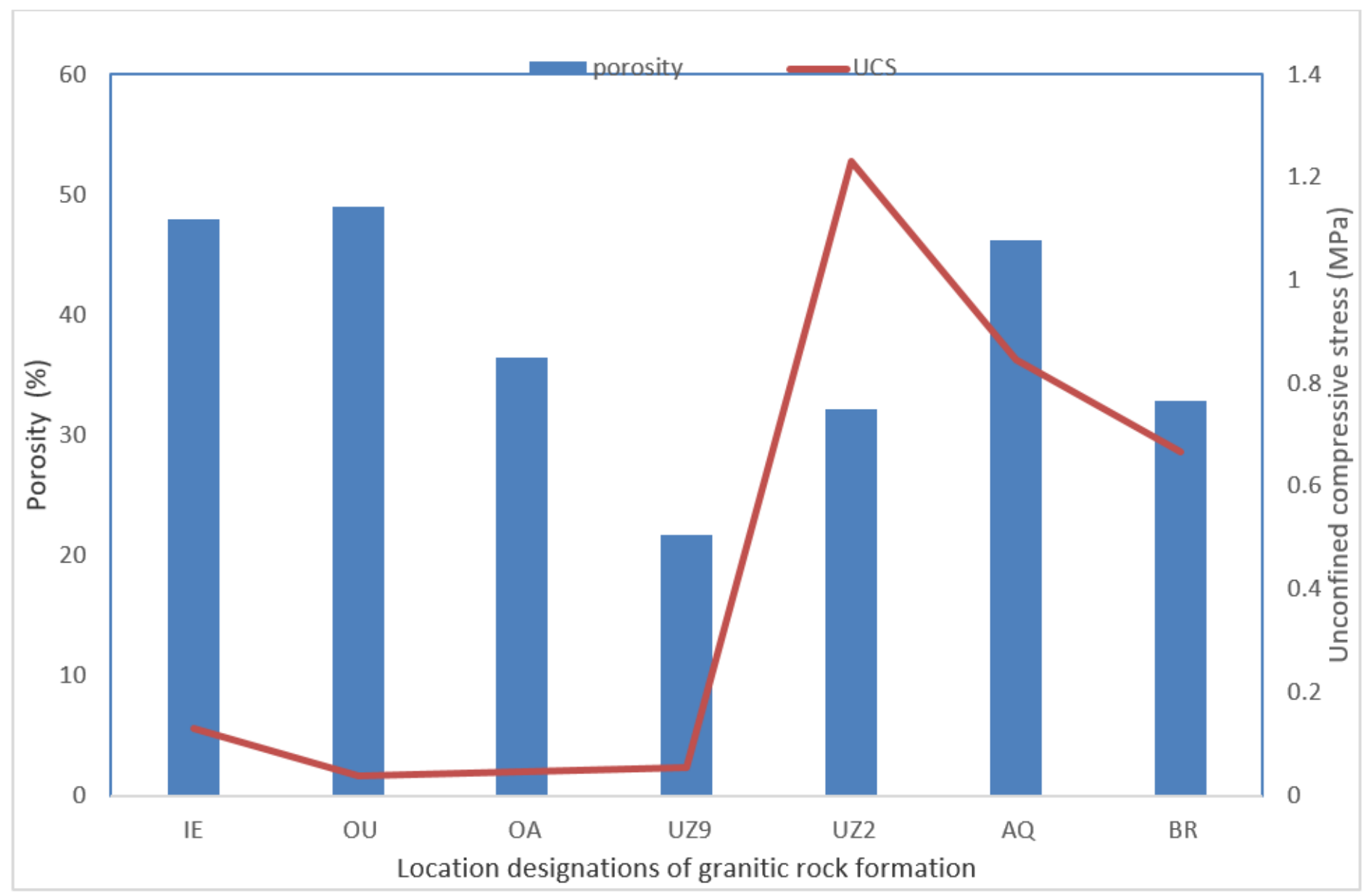

Figure 4

Porosity and unconfined compressive strength data of granite rocks. 


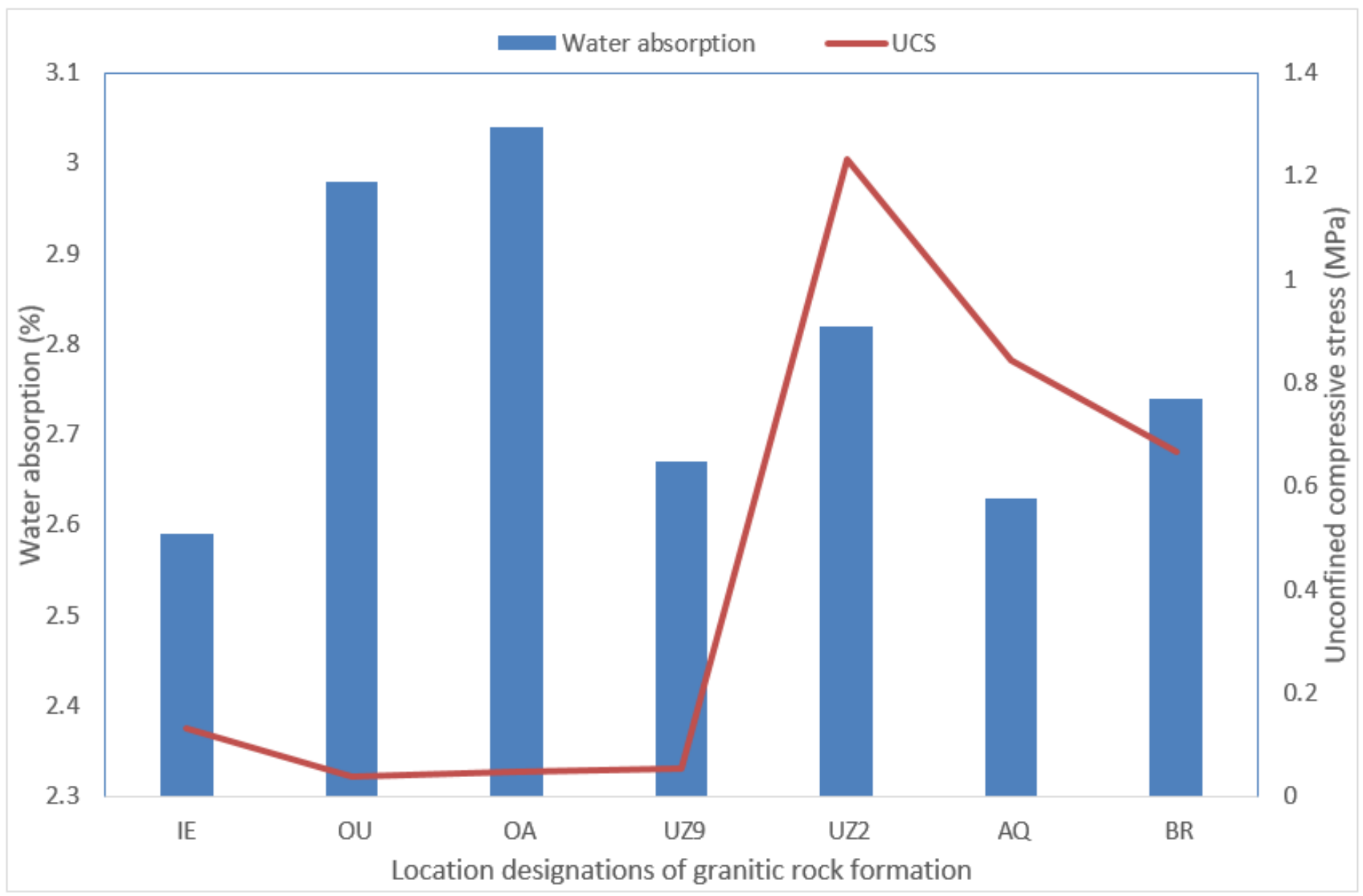

Figure 5

Water absorption and unconfined compressive strength data of granite rocks. 